\title{
Distribution of heavy metals in fish organs, associated water and sediment from Ero Dam, Ekiti State, Nigeria
}

\author{
Ajayi Ilesanmi OSASONA ${ }^{1^{*}}$, Kolade Oloruntoba IPINMOROTI ${ }^{2}$ and \\ Albert Ojo ADEBAYO ${ }^{2}$ \\ ${ }^{I}$ Department of Chemical Sciences, Afe Babalola University, PMB 5454, Ado- Ekiti, Nigeria. \\ ${ }^{2}$ Department of Chemistry, Federal University of Technology,PMB 704, Akure, Nigeria. \\ Corresponding author, E-mail: oosasona@yahoo.com; Tel: +2348030656679
}

\begin{abstract}
An investigation into the distribution of lead, manganese, copper, zinc, mercury, iron, chromium and cadmium in the sediment, water and the organs of Oreochromis niloticus, Tilapia zillii, African catfish (Clarias gariepinus) and Citharinus citerus obtained from Ero Dam in Ikun-Ekiti, Ekiti State, Nigeria was undertaken. This was done to ascertain the presence of these metals in the three matrixes and to determine the bioaccumulation factors of these metals in the organs of these fishes. The three matrixes were differently digested and analysed for heavy metals using Atomic Absorption Spectrophotometer (Buck 200). Hg was determined via cold vapour generation. The levels of the metals in water were very much lower than their corresponding concentrations in the sediment. In the same vein, concentrations of the metals in the fish organs were higher than those recorded for the water except $\mathrm{Cu}$ and $\mathrm{Mn}$ that showed slight variations. The most concentrated metal in the organs of the four fish species was $\mathrm{Zn}$ which recorded concentrations $(\mathrm{mg} / \mathrm{kg}$ ) ranging from $7.36 \pm 0.03$ in the head of Clarias gariepinus to 8.12 \pm 0.13 in that of Citharinus citerus. In Clarias gariepinus, $\mathrm{Cr}, \mathrm{Cd}$ and $\mathrm{Hg}$ were only detected in its gills. On the contrary, all the metals were detected in the organs of Oreochromis niloticus and Tilapia zillii. $\mathrm{Zn}, \mathrm{Mn}$ and $\mathrm{Fe}$ were the three most abundant metals in the organs of these fishes. The highly toxic metals $(\mathrm{Pb}, \mathrm{Cd}$ and $\mathrm{Hg})$ in this determination were either not detected or detected at low levels. It is obvious from this work that $\mathrm{Zn}$ was bioaccumulated most in the organs of each fish. It is certain that heavy metals are present in Ero dam but in low concentrations. This calls for constant monitoring because as industries are established in Ekiti State, Nigeria, the level of heavy metals in this dam may increase.
\end{abstract}

(C) 2011 International Formulae Group. All rights reserved.

Keywords: Oreochromis niloticus, Tilapia zillii, Citharinus citerus.

\section{INTRODUCTION}

Metals are introduced into our aquatic system as contaminants via several ways which include weathering of rocks, dissolution of aerosol particles from the atmosphere and from several human activities (Adefemi et al., 2004). Once these metals get into the aquatic environment, they may be precipitated, adsorbed on solid surface, remain soluble, suspended in water or may be taken 
up and accumulated in the body part of aquatic organisms (Ipinmoroti et al., 1997a). Bioaccumulation and magnification is capable of leading to toxic level of these metals in fish, even when the exposure is low (Ipinmoroti et al., 1997b; Ekeanyawu et al., 2010).

Ero Dam, which was established in 1983 , is located in Ikun-Ekiti (latitude $7^{0} 59^{\prime} \mathrm{N}$ and longitude $5^{0} 12^{\prime} \mathrm{E}$ ), Moba Local Government Area of Ekiti State, Nigeria. It covers a distance of about $11 \mathrm{~km}$. The dam supplies over one hundred towns and villages in the state with pipe born water. Ekiti State, one of the youngest states in Nigeria, was carved out of the old Ondo State in 1996, and therefore has very low industrial activities. In fact, more than seventy percent of the inhabitants of this state are farmers (majority of which are on subsistent scale). The possible sources of heavy metals to Ero dam include: run off water, exhaust fumes from vehicles and different agricultural chemicals used by farmers.

Fishes are notorious for their ability to concentrate metals in their muscles (Okoye, 1991). Fish is valuable in the diet because apart from supplying good quality protein and vitamins $\mathrm{A}$ and $\mathrm{D}$, it also contains several metals such as $\mathrm{Ca}, \mathrm{Fe}$, etc which are beneficial to man (Adeyeye, 1997). However, toxic metals such as $\mathrm{Pb}, \mathrm{Cd}$, etc may also be present especially if the environment of the fish is polluted. Considering the ability of fishes in concentrating metals in their bodies, their importance in human nutrition and the rate at which they are consumed, fishes need to be carefully screened. This will ensure that unnecessarily high levels of toxic metals are not being transferred to man through fishes.

Little attention has been paid to the comparative study of metal concentrations in the three matrixes of sediment, water and fish of any water reservoir. Reported works include those of: Adefemi et al., 2004; Gupta et al., 2009; Ekeanyanwu et al., 2010; Olowu et al., 2010; Ali et al., 2010. This work focuses on the determination of $\mathrm{Zn}, \mathrm{Mn}, \mathrm{Cr}$, $\mathrm{Cd}, \mathrm{Hg}, \mathrm{Fe}, \mathrm{Pb}$ and $\mathrm{Cu}$ in these three matrixes.

\section{MATERIALS AND METHODS \\ Collection and treatment of samples}

Water and sediment samples were collected and treated as described in literature (Adeyeye, 1997). Five of each of Oreochromis niloticus, Tilapia zillii, African Catfish (Clarias gariepinus) and Citharinus citerus (the four major fish species found in Ero dam) were caught from the dam with a net. Each fish was briefly washed with distilled water to remove any adhering substances. Each fish sample was drained under the fold of filter paper, wrapped in aluminum foil and deep frozen prior to analysis.

\section{Analysis of samples}

Five milliliter $(5 \mathrm{ml})$ of concentrated $\mathrm{HNO}_{3}(63 \%)$ was added to $250 \mathrm{ml}$ of water sample and evaporated to $25 \mathrm{ml}$. The concentrate was transferred to a $50 \mathrm{ml}$ standard flask and diluted to the mark with distilled water. The resultant solution was analysed for heavy metals using Atomic Absorption Spectrophotometer (Buck 200). The methods of AOAC (1990) were used for the treatment and digestion of the fish samples while the sediment was treated and digested using the methods of Adeyeye et al. (1996). Analysis of resultant solutions was done using Atomic Absorption Spectrophotometer (Buck 200).

\section{Statistical analysis}

Statistical analysis of data was performed using SPSS statistical package program. Duncan Multiple Range Test was carried out; means in the same column which are not significantly different $(p>0.05)$ are indicated with the same superscript. 


\section{RESULTS}

The result of heavy metals determined in the sediment and surface water is shown in Figure 1. The figure reveals the concentrations of the metals in water in the order $\mathrm{Mn}>\mathrm{Zn}>\mathrm{Fe}>\mathrm{Cu} . \mathrm{Pb}, \mathrm{Cr}, \mathrm{Hg}$ and $\mathrm{Cd}$ were not detected in the water. The values recorded for the metals, except for Mn, are all within the WHO standards for drinking water (Table 1). This, coupled with non detection of the highly toxic metals $(\mathrm{Pb}, \mathrm{Cd}$ and $\mathrm{Hg})$, shows that the water of this dam is safe for drinking. The levels of metals in the sediment also followed the same order $\mathrm{Mn}>\mathrm{Zn}>\mathrm{Fe}>\mathrm{Cu}$.

Table 2 indicates that $\mathrm{Zn}, \mathrm{Mn}$ and $\mathrm{Fe}$ were the three most abundant metals in the organs of Clarias gariepinus. $\mathrm{Zn}$ values $(\mathrm{mg} / \mathrm{kg})$ ranged from $4.46 \pm 0.06$ (eyes) $7.36 \pm 0.03$ (head), Mn had values ranging from $3.17 \pm 0.03$ (head) - $4.84 \pm 0.06$ (internal organs) and iron values ranged from $1.16 \pm 0.07$ (body tissue) to $1.35 \pm 0.04$ (gills). These three metals and $\mathrm{Cu}$ were the only metals detected in all the organs of this fish. The general order of distribution of heavy metals in the organs of Clarias gariepinus is $\mathrm{Zn}>\mathrm{Mn}>\mathrm{Fe}>\mathrm{Cu}>\mathrm{Pb} . \mathrm{Cr}, \mathrm{Cd}$ and $\mathrm{Hg}$, which were only detected in the gills, all had the same concentration of $0.01 \mathrm{mg} / \mathrm{kg}$.

Table 3 also reveals $\mathrm{Zn}, \mathrm{Mn}$ and $\mathrm{Fe}$ to be the three most concentrated metals in the organs of Oreochromis niloticus. The head of Oreochromis niloticus recorded the highest concentrations of $\mathrm{Zn}(7.48 \pm 0.12 \mathrm{mg} / \mathrm{kg})$ and $\mathrm{Fe}(3.25 \pm 0.01 \mathrm{mg} / \mathrm{kg})$. This shows that the head of this fish (Oreochromis niloticus) is a good source of these beneficial elements. $\mathrm{Zn}$, $\mathrm{Mn}$ and $\mathrm{Fe}$ were also observed to be the most abundant heavy metals in the organs of Tilapia zillii (Table 4). The highest concentrations of $\mathrm{Zn}(7.63 \pm 0.16 \mathrm{mg} / \mathrm{kg})$ and Fe $(3.36 \pm 0.10)$ were found in the head. For $\mathrm{Mn}$ its highest concentration was detected in the gills. The levels of the highly toxic metals $(\mathrm{Pb}, \mathrm{Cd}$ and $\mathrm{Hg})$ in Tilapia zillii were very low.

Table 5 presents the results of heavy metals determined in the organs of Citharinus citerus. All the metals determined were detected in the organs of this fish except lead and chromium which were not detected in the internal organs and the head, respectively. The head of this fish had the highest levels of $\mathrm{Zn}$ and $\mathrm{Fe}$ as observed for Tilapia zillii. and Oreochromis niloticus. The order of bioaccumulation factors (Figures 2, 3, 4 and 5) for the various species of fish in this determination are as follows: Clarias gariepinus (Figure 2):- $\mathrm{Zn}>\mathrm{Cu}>\mathrm{Fe}>\mathrm{Mn}$, Oreochromis niloticus(Figure 3):- $\mathrm{Zn}>$ $\mathrm{Fe}>\mathrm{Mn}>\mathrm{Cu}$, Tilapia zillii (Figure 4):$\mathrm{Zn}>\mathrm{Fe}>\mathrm{Cu}>\mathrm{Mn}$ and Citharinus citerus (Figure 5):- $\mathrm{Zn}>\mathrm{Fe}>\mathrm{Mn}>\mathrm{Cu}$.

Table 1: WHO standards for drinking water.

\begin{tabular}{lcccccccc}
\hline Metal & Mn & Pb & $\mathbf{C r}$ & $\mathbf{C u}$ & $\mathbf{C d}$ & $\mathbf{H g}$ & $\mathbf{F e}$ & $\mathbf{Z n}$ \\
\hline WHO $^{\mathrm{a}}$ & 0.1 & 0.01 & 0.05 & 2.00 & 0.003 & 0.001 & 0.30 & 3.0
\end{tabular}

${ }^{\mathrm{a}}$ (WHO, 1993) 
Table 2: Concentration of heavy metals in the organs of African catfish (Clarias gariepinus) in $\mathrm{mg} / \mathrm{kg}$ dry weight.

\begin{tabular}{lccccc}
\hline Head & Eyes & Gills & $\begin{array}{c}\text { Body } \\
\text { Tissue }\end{array}$ & $\begin{array}{c}\text { Internal } \\
\text { Organs }\end{array}$ \\
\hline $\mathrm{Mn}$ & $3.17^{\mathrm{d}} \pm 0.03$ & $3.78^{\mathrm{c}} \pm 0.12$ & $4.45^{\mathrm{d}} \pm 0.005$ & $3.96^{\mathrm{d}} \pm 0.05$ & $4.84^{\mathrm{d}} \pm 0.06$ \\
$\mathrm{~Pb}$ & $\mathrm{ND}$ & $0.001^{\mathrm{a}} \pm 0.00$ & $0.01^{\mathrm{a}} \pm 0.01$ & $0.01^{\mathrm{a}} \pm 0.01$ & $\mathrm{ND}$ \\
$\mathrm{Cr}$ & $\mathrm{ND}$ & $\mathrm{ND}$ & $0.01^{\mathrm{a}} \pm 0.00$ & $\mathrm{ND}$ & $\mathrm{ND}$ \\
$\mathrm{Cu}$ & $0.41^{\mathrm{b}} \pm 0.01$ & $0.23^{\mathrm{a}} \pm 0.03$ & $0.54^{\mathrm{b}} \pm 0.05$ & $0.34^{\mathrm{b}} \pm 0.06$ & $0.38^{\mathrm{b}} \pm 0.03$ \\
$\mathrm{Cd}$ & $\mathrm{ND}$ & $\mathrm{ND}$ & $0.01^{\mathrm{a}} \pm 0.00$ & $\mathrm{ND}$ & $\mathrm{ND}$ \\
$\mathrm{Hg}$ & $\mathrm{ND}$ & $\mathrm{ND}$ & $0.01^{\mathrm{a}} \pm 0.00$ & $\mathrm{ND}$ & $\mathrm{ND}$ \\
$\mathrm{Fe}$ & $1.26^{\mathrm{c}} \pm 0.02$ & $1.23^{\mathrm{b}} \pm 0.33$ & $1.35^{\mathrm{c}} \pm 0.04$ & $1.16^{\mathrm{c}} \pm 0.07$ & $1.18^{\mathrm{c}} \pm 0.01$ \\
$\mathrm{Zn}$ & $7.36^{\mathrm{e}} \pm 0.03$ & $4.46^{\mathrm{d}} \pm 0.06$ & $6.89^{\mathrm{e}} \pm 0.10$ & $5.72^{\mathrm{e}} \pm 0.64$ & $6.72^{\mathrm{e}} \pm 0.12$ \\
\hline
\end{tabular}

Mean \pm standard deviation for triplicate determinations; means with the same superscript in the same column do not differ ( $>$ > 0.05).

Table 3: Concentration of heavy metals in the organs of Oreochromis niloticus in $\mathrm{mg} / \mathrm{kg}$ dry weight.

\begin{tabular}{lccccc}
\hline & Head & Eyes & Gills & $\begin{array}{c}\text { Body } \\
\text { Tissue }\end{array}$ & $\begin{array}{c}\text { Internal } \\
\text { Organs }\end{array}$ \\
\hline $\mathrm{Mn}$ & $2.75^{\mathrm{b}} \pm 0.06$ & $1.25^{\mathrm{c}} \pm 0.06$ & $5.02^{\mathrm{d}} \pm 0.10$ & $1.50^{\mathrm{c}} \pm 0.08$ & $1.46^{\mathrm{b}} \pm 0.12$ \\
$\mathrm{~Pb}$ & $0.005^{\mathrm{a}} \pm 0.00$ & $0.008^{\mathrm{a}} \pm 0.001$ & $0.001^{\mathrm{a}} \pm 0.00$ & $0.013^{\mathrm{a}} \pm 0.002$ & $0.003^{\mathrm{a}} \pm 0.00$ \\
$\mathrm{Cr}$ & $0.004^{\mathrm{a}} \pm 0.001$ & $0.001^{\mathrm{a}} \pm 0.00$ & $0.007^{\mathrm{a}} \pm 0.001$ & $0.001^{\mathrm{a}} \pm 0.00$ & $0.004^{\mathrm{a}} \pm 0.00$ \\
$\mathrm{Cu}$ & $0.05^{\mathrm{a}} \pm 0.001$ & $0.001^{\mathrm{a}} \pm 0.00$ & $0.007^{\mathrm{a}} \pm 0.01$ & $0.008^{\mathrm{a}} \pm 0.01$ & $0.012^{\mathrm{a}} \pm 0.00$ \\
$\mathrm{Cd}$ & $0.002^{\mathrm{a}} \pm 0.00$ & $0.003^{\mathrm{a}} \pm 0.00$ & $0.007^{\mathrm{a}} \pm 0.00$ & $0.009^{\mathrm{a}} \pm 0.00$ & $0.006^{\mathrm{a}} \pm 0.00$ \\
$\mathrm{Hg}$ & $0.006^{\mathrm{a}} \pm 0.00$ & $0.003^{\mathrm{a}} \pm 0.00$ & $0.12^{\mathrm{a}} \pm 0.02$ & $0.007^{\mathrm{a}} \pm 0.00$ & $0.01^{\mathrm{a}} \pm 0.00$ \\
$\mathrm{Fe}$ & $3.25^{\mathrm{c}} \pm 0.01$ & $1.035^{\mathrm{b}} \pm 0.032$ & $1.05^{\mathrm{b}} \pm 0.062$ & $1.1^{\mathrm{b}} \pm 0.01$ & $2.51^{\mathrm{c}} \pm 0.09$ \\
$\mathrm{Zn}$ & $7.48^{\mathrm{d}} \pm 0.12$ & $4.06^{\mathrm{d}} \pm 0.08$ & $4.63^{\mathrm{c}} \pm 0.33$ & $3.42^{\mathrm{d}} \pm 0.00$ & $6.10^{\mathrm{d}} \pm 0.10$ \\
\hline $\mathrm{Mean} \pm$ standard deviation for triplicate determinations; & means with the same superscript in the same column do not differ \\
(p>0.05). &
\end{tabular}

Table 4: Concentration of heavy metals in the organs of Tilapia zillii in $\mathrm{mg} / \mathrm{kg}$ dry weight.

\begin{tabular}{lccccc}
\hline & Head & Eyes & Gills & $\begin{array}{c}\text { Body } \\
\text { Tissue }\end{array}$ & $\begin{array}{c}\text { Internal } \\
\text { Organs }\end{array}$ \\
\hline $\mathrm{Mn}$ & $2.82^{\mathrm{b}} \pm 0.03$ & $1.37^{\mathrm{b}} \pm 0.09$ & $5.34^{\mathrm{d}} \pm 0.01$ & $1.64^{\mathrm{c}} \pm 0.01$ & $1.38^{\mathrm{b}} \pm 0.05$ \\
$\mathrm{~Pb}$ & $0.007^{\mathrm{a}} \pm 0.03$ & $0.011^{\mathrm{a}} \pm 0.01$ & $0.013^{\mathrm{a}} \pm 0.02$ & $0.016^{\mathrm{a}} \pm 0.00$ & $0.005^{\mathrm{a}} \pm 0.00$ \\
$\mathrm{Cr}$ & $0.025^{\mathrm{a}} \pm 0.00$ & $0.002^{\mathrm{a}} \pm 0.00$ & $0.01^{\mathrm{a}} \pm 0.006$ & $0.013^{\mathrm{a}} \pm 0.00$ & $0.004^{\mathrm{a}} \pm 0.002$ \\
$\mathrm{Cu}$ & $0.07^{\mathrm{a}} \pm 0.001$ & $0.003^{\mathrm{a}} \pm 0.00$ & $0.11^{\mathrm{a}} \pm 0.02$ & $0.01^{\mathrm{a}} \pm 0.001$ & $0.015^{\mathrm{a}} \pm 0.01$ \\
$\mathrm{Cd}$ & $0.003^{\mathrm{a}} \pm 0.00$ & $0.005^{\mathrm{a}} \pm 0.001$ & $0.01^{\mathrm{a}} \pm 0.00$ & $0.011^{\mathrm{a}} \pm 0.003$ & $0.01^{\mathrm{a}} \pm 0.00$ \\
$\mathrm{Hg}$ & $0.008^{\mathrm{a}} \pm 0.00$ & $0.005^{\mathrm{a}} \pm 0.01$ & $0.015^{\mathrm{a}} \pm 0.02$ & $0.009^{\mathrm{a}} \pm 0.00$ & $0.013^{\mathrm{a}} \pm 0.002$ \\
$\mathrm{Fe}$ & $3.36^{\mathrm{c}} \pm 0.10$ & $1.29^{\mathrm{b}} \pm 0.08$ & $1.12^{\mathrm{b}} \pm 0.04$ & $1.32^{\mathrm{b}} \pm 0.06$ & $2.65^{\mathrm{c}} \pm 0.15$ \\
$\mathrm{Zn}$ & $7.63^{\mathrm{d}} \pm 0.16$ & $4.13^{\mathrm{c}} \pm 0.11$ & $4.81^{\mathrm{c}} \pm 0.043$ & $3.96^{\mathrm{c}} \pm 0.06$ & $6.24^{\mathrm{d}} \pm 0.06$ \\
\hline
\end{tabular}

Mean \pm standard deviation for triplicate determinations; means with the same superscript in the same column do not differ $(\mathrm{p}>0.05)$. 
Table 5: Concentration of heavy metals in the organs of Citharinus citerus in $\mathrm{mg} / \mathrm{kg}$ dry weight.

\begin{tabular}{lccccc}
\hline & Head & Eyes & Gills & $\begin{array}{c}\text { Body } \\
\text { Tissue }\end{array}$ & $\begin{array}{c}\text { Internal } \\
\text { Organs }\end{array}$ \\
\hline $\mathrm{Mn}$ & $3.16^{\mathrm{b}} \pm 0.003$ & $1.43^{\mathrm{b}} \pm 0.012$ & $4.91^{\mathrm{c}} \pm 0.16$ & $1.74^{\mathrm{a}} \pm 0.009$ & $1.53^{\mathrm{b}} \pm 0.18$ \\
$\mathrm{~Pb}$ & $0.005^{\mathrm{a}} \pm 0.00$ & $0.01^{\mathrm{a}} \pm 0.005$ & $0.11^{\mathrm{a}} \pm 0.03$ & $0.02^{\mathrm{a}} \pm 0.00$ & $\mathrm{ND}$ \\
$\mathrm{Cr}$ & $\mathrm{ND}$ & $0.004^{\mathrm{a}} \pm 0.00$ & $0.007^{\mathrm{a}} \pm 0.002$ & $0.011^{\mathrm{a}} \pm 0.00$ & $0.006^{\mathrm{a}} \pm 0.00$ \\
$\mathrm{Cu}$ & $0.09^{\mathrm{a}} \pm 0.00$ & $0.006^{\mathrm{a}} \pm 0.00$ & $0.015^{\mathrm{a}} \pm 0.00$ & $0.016^{\mathrm{a}} \pm 0.003$ & $0.02^{\mathrm{a}} \pm 0.01$ \\
$\mathrm{Cd}$ & $0.005^{\mathrm{a}} \pm 0.001$ & $0.008^{\mathrm{a}} \pm 0.002$ & $0.006^{\mathrm{a}} \pm 0.001$ & $0.008^{\mathrm{a}} \pm 0.001$ & $0.11^{\mathrm{a}} \pm 0.03$ \\
$\mathrm{Hg}$ & $0.087^{\mathrm{a}} \pm 0.001$ & $0.004^{\mathrm{a}} \pm 0.00$ & $0.015^{\mathrm{a}} \pm 0.002$ & $0.013^{\mathrm{a}} \pm 0.003$ & $0.17 \mathrm{a} \pm 0.03$ \\
$\mathrm{Fe}$ & $4.43^{\mathrm{c}} \pm 0.19$ & $1.35^{\mathrm{b}} \pm 0.14$ & $1.38^{\mathrm{b}} \pm 0.11$ & $0.38^{\mathrm{b}} \pm 0.01$ & $2.89^{\mathrm{c}} \pm 0.04$ \\
$\mathrm{Zn}$ & $8.12^{\mathrm{d}} \pm 0.13$ & $4.62^{\mathrm{c}} \pm 0.15$ & $5.32^{\mathrm{d}} \pm 0.09$ & $4.12^{\mathrm{d}} \pm 0.03$ & $6.33^{\mathrm{d}} \pm 0.26$ \\
\hline Mean \pm standard deviation for triplicate determinations; means with the same superscript in the same column do not differ \\
(p>0.05).
\end{tabular}

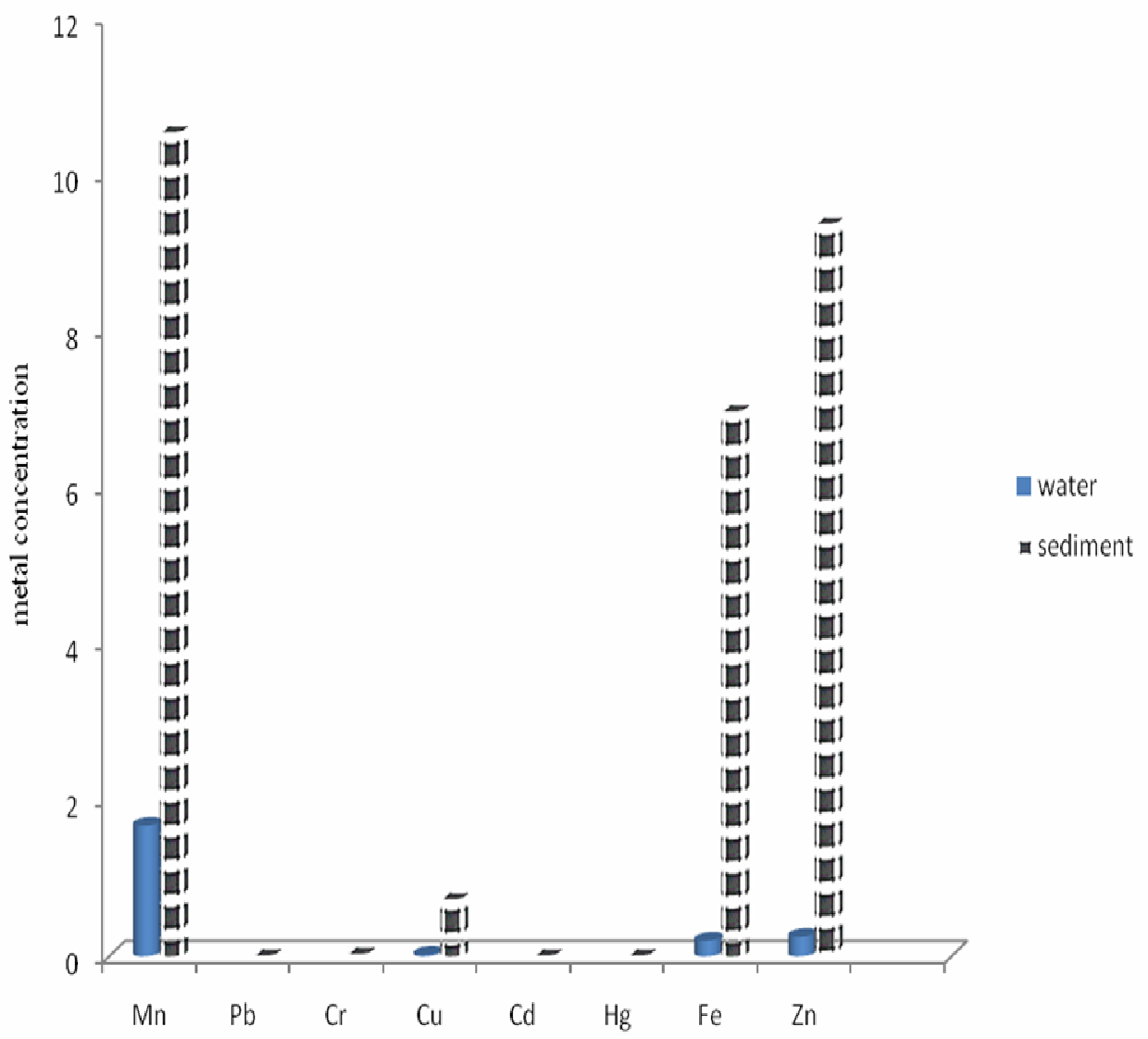

Figure 1: Concentration of heavy metals in water $(\mathrm{mg} / \mathrm{L})$ and sediment $(\mathrm{mg} / \mathrm{kg})$. 


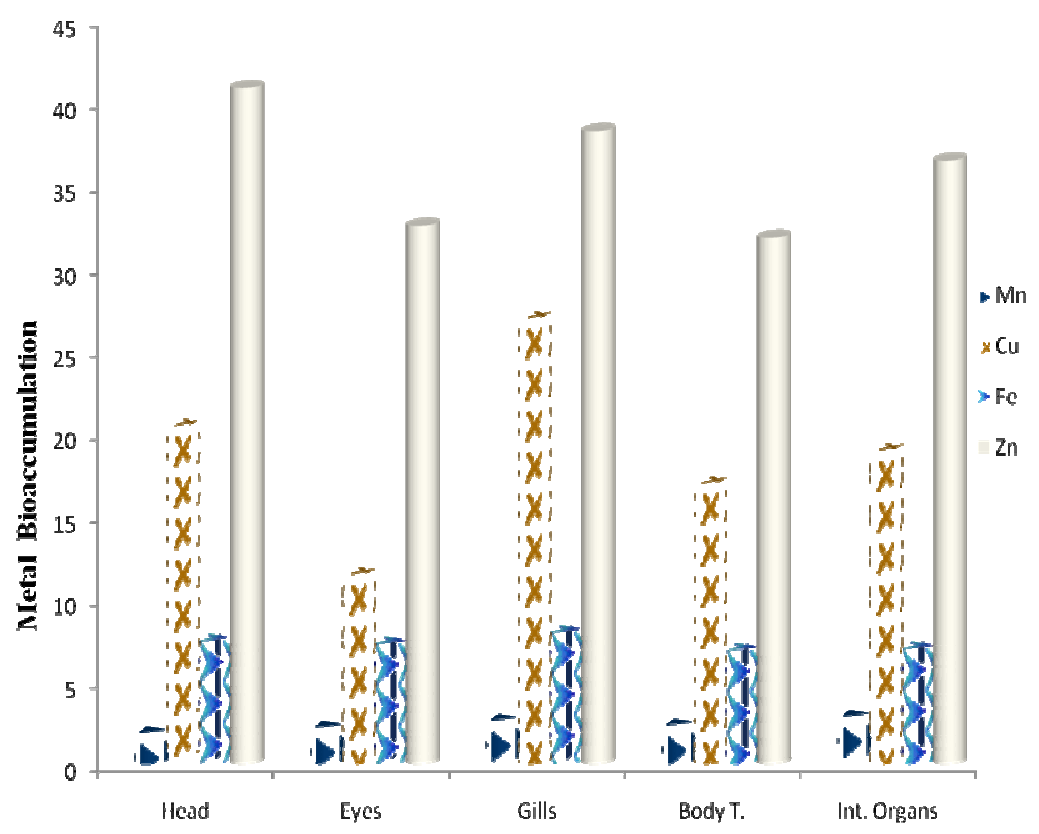

Figure 2: Bioaccumulation factors of heavy metals in the organs of Clarias gariepinus.

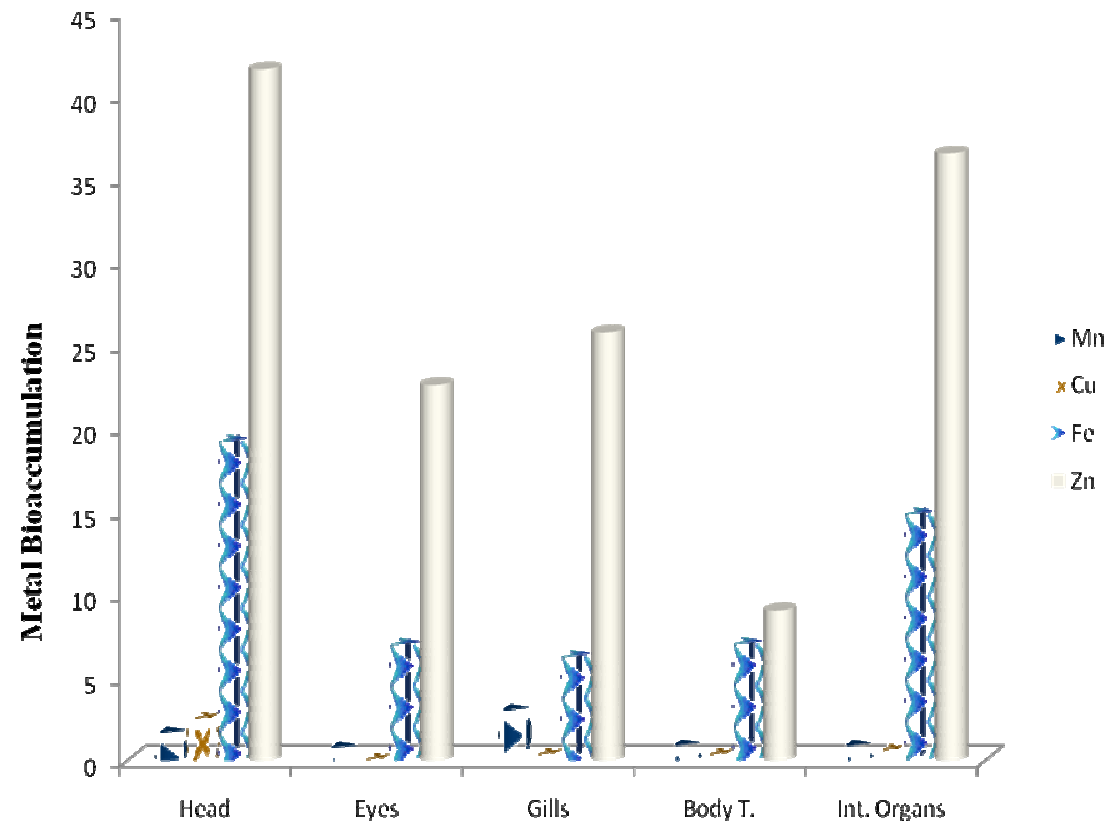

Figure 3: Bioaccumulation factors of heavy metals in the organs of Oreochromis niloticus. 


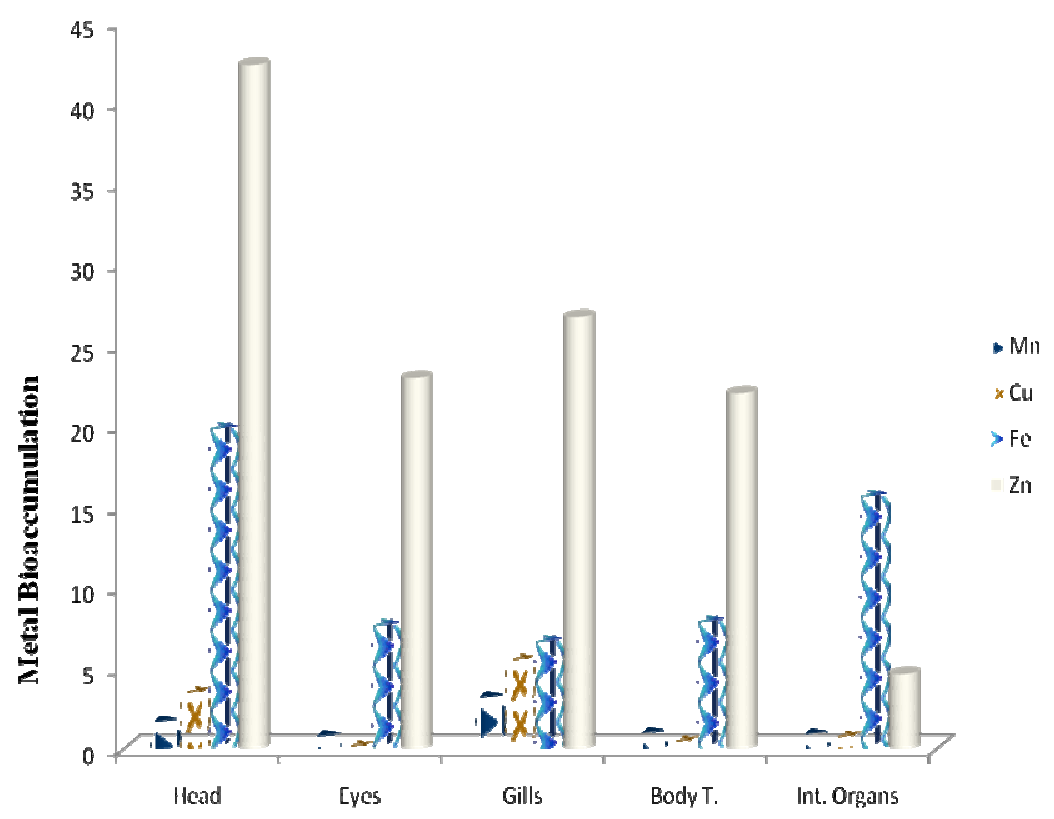

Figure 4: Bioaccumulation factors of heavy metals in the organs of Tilapia zillii.

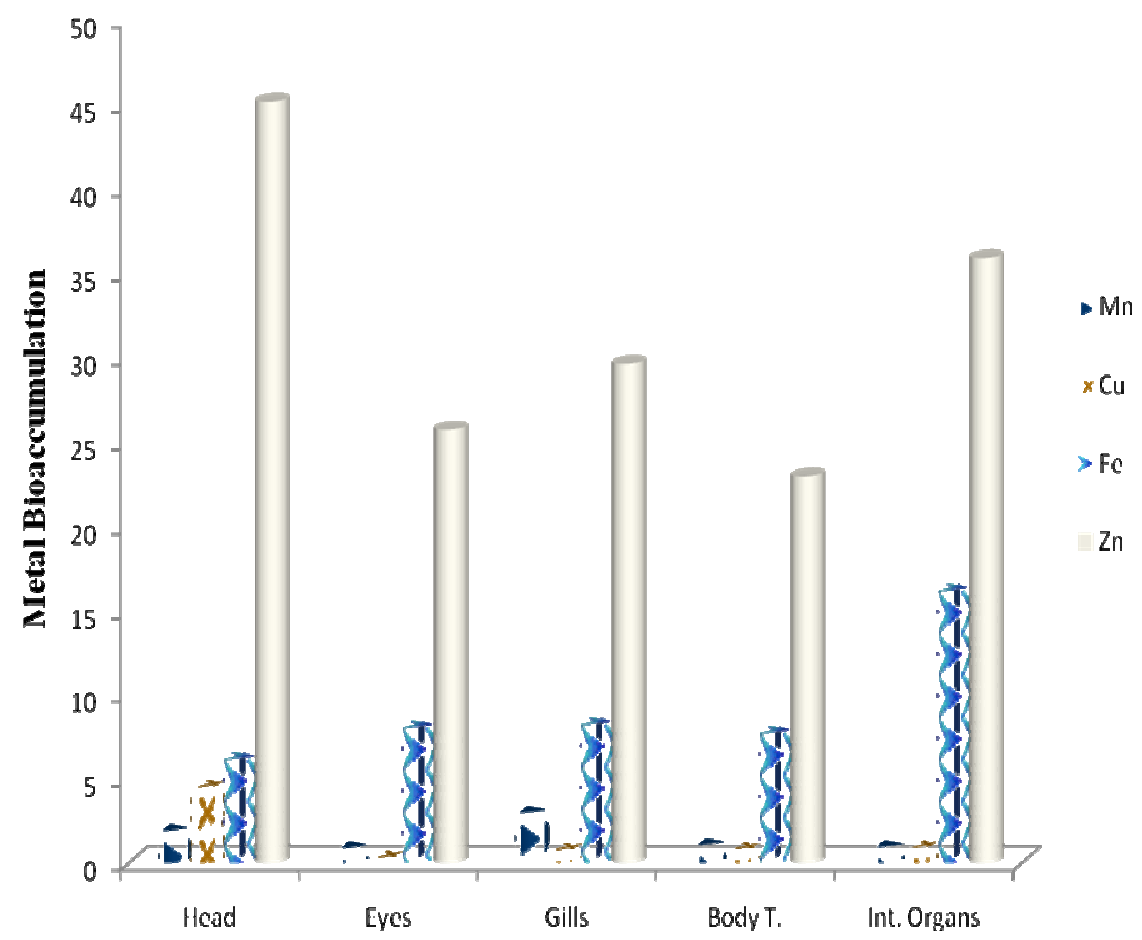

Figure 5: Bioaccumulation factors of heavy metals in the organs of Citharinus citerus. 


\section{DISCUSSION}

The result of heavy metals determined in the sediment and surface water (Figure 1) shows clearly that the concentrations of metals in the water were lower than those obtained for the sediment. This is in complete agreement with earlier literature reports (Adefemi et al., 2004; Ali et al., 2010; Ekeanyawu et al., 2010). Metals like Cr, Hg, $\mathrm{Pb}$ and $\mathrm{Cd}$ which were not detectable in the water were detected at very low level in the sediment (Figure 1). These observations could be attributed to the fact that sediments form the major repository of heavy metals in aquatic system (Adeniyi and Yusuf, 2007). The higher concentration of heavy metals in the sediment may be linked to the activities of farmers (which may include the use of pesticides, and herbicides) who have farms close to the dam. Manganese, zinc and iron, the three most abundant heavy metals in the water of Ero dam are comparatively nontoxic. For example, $\mathrm{Fe}$ is not toxic in water but can produce some annoying effects such as stains on clothing and giving water an undesirable colour and taste. These three metals have been reported to be the most abundant heavy metals in soil and water of Ekiti (Adefemi et al., 2004; Adeyeye, 2005).

The highly toxic metals in this study $(\mathrm{Pb}, \mathrm{Cd}$ and $\mathrm{Hg}$ ) were not detected in the organs (head and body tissue) of Clarias gariepinus that are usually consumed by man. It is worthy of note to observe that while all other organs of this fish had 3 or 4 heavy metals not present, the gills had all the metals present. Furthermore, the gills seemed to contain higher concentrations of metals than other organs except the internal organs and the head that had higher concentrations of Mn and $\mathrm{Zn}$, respectively (Table 2). The fact that metal uptake in fish occurs through absorption across the gills surface or through the digestive tract during food intake (Adefemi et al., 2004) could have accounted for this observation. This observation could make one suggest that the gills of Clarias gariepinus could be used to monitor the level of pollution of this dam.

The highly toxic metals $(\mathrm{Pb}, \mathrm{Cd}$ and $\mathrm{Hg}$ ) which were not detected in most of the organs of Clarias gariepinus were all detected in Oreochromis niloticus (Table 3). Of these, $\mathrm{Hg}$ recorded the highest value and this was detected in the gills. $\mathrm{Pb}$ and $\mathrm{Cd}$ recorded their respective highest concentrations in the body tissue. Each of these highly toxic metals had an approximate concentration of $0.01 \mathrm{mg} / \mathrm{kg}$ in the body tissue. The body tissue of this fish seemed to concentrate $\mathrm{Pb}$ and $\mathrm{Cd}$ more than other organs. This calls for attention because this is the part of the fish mostly consumed by man. It is obvious from this determination that $\mathrm{Zn}$ was the most bioaccumulated metal in the organs of the four fish species (Figure 2-5). The head of each fish specie bioaccumulated $\mathrm{Zn}$ more than any other organ. This shows that the heads of fish in Ero dam are a good source of this beneficial element. Bioaccumulation factors could not be determined for $\mathrm{Cr}, \mathrm{Cd}$, $\mathrm{Hg}$ and $\mathrm{Pb}$ because they were not detected in water.

Generally, for the detected metals in the three matrices of water, sediment and fish organs, $\mathrm{Zn}, \mathrm{Mn}$ and $\mathrm{Fe}$ were found to be the most abundant. The high concentrations of manganese iron and zinc in the fish organs could be associated with the fact that these metals are naturally abundant in Nigeria soils (Olowu et al., 2010). Since these metals are beneficial to man, the four fish species will complement the supply of $\mathrm{Zn}, \mathrm{Fe}$ and $\mathrm{Mn}$ in food. $\mathrm{Zn}$ is involved in nucleic acid synthesis, iron in the synthesis of haemoglobin and manganese functions as an essential constituent of bone structure, for reproduction and normal functioning of the nervous system (Adeyeye, 1997). The concentrations of heavy metals recorded for the water of Ero dam are within the WHO standards for drinking water. This shows that the dam is not polluted with heavy metals.

It is hoped that as Ekiti State industrialises, the level of heavy metals in this dam may increase. This, therefore, calls for 
continuous monitoring of this dam and others that supply water for public consumption in the state. The gills of any of the fish species could be used for this monitoring, since all the metals determined were detected in the gills of all the fish species.

\section{REFERENCES}

Adefemi OS, Asaolu SS, Olaofe OO. 2004. Concentration of heavy metals in water, sediment and fish parts of Illisa africana from Ureje Dam, Ado-Ekiti, Nigeria. Journal of Biological and Physical Sciences, 1:114-117.

Adeniyi AA, Yusuf KA. 2007. Determination of heavy metals in fish tissues, water and bottom sediments from Epe and Badagry Lagoons, Lagos, Nigeria. Environmental Monitoring and Assessement, 37: 451-458.

Adeyeye EI. 1997. Water quality criteria and the relationship between them and concentration of some mineral elements in soil sediments, ambient water and the body parts of Clarias gariepinu fish in a fresh water pond. Ghana Journal of Chemistry, 2: 42- 50.

Adeyeye EI. 2005. Trace metals in soils and plants from FADAMA Farms in Ekiti State, Nigeria. Bull. Chem. Soc. Ethiop., 19(1): 23-34.

Adeyeye EI, Akinyugha NJ, Fesobi ME, Tenabe VO. 1996. Determination of some metals in Clarias gariepinus, Cyprinus caripo(L) and Oreochromis niloticus fish in a poly-culture fresh water pond and their environment. Aquaculture, 147: 205-214.

Ali A, Ahmadou D, Mohamadou BA, Saidou C, Tenin D. 2010. Determination of minerals and heavy metals in water, sediments and three fis species (Tilapia nilotica, Silurus glanis and Arius parkii) from Lagdo lake, Cameroun. Journal of Fisheries International, 5(3): 54-57.
AOAC (Association of Official Analytical Chemists). 1990. Official Methods of Analysis (15 ${ }^{\text {th }}$ edition). Association of Analytical Chemists: Wasghiton DC.

Ekeanyanwu CR, Ogbuinyi CA, Etienajirhevwe OF. 2010. Trace metals distribution in fish tissues, bottom sediments and water from Okumeshi River in Delta State, Nigeria. Ethiopian Journal of Environmental Studies and Management, 3(3): 12-17.

Gupta A, Devendra KR, Ravi SP, Bechan S. 2009. Analysis of some heavy metals in the riverine water, sediments and fish from river Ganges at Allahabad. Environ Monit Assess, 157: 449-458.

Ipinmoroti KO, Asaolu SS, Adeeyinwo CE, Olaofe OO. 1997a. Distribution of some heavy metals in coastal water of Ondo State, Nigeria. The J. Techno-sci., 1(8): 46-51.

Ipinmoroti KO, Oshodi AA, Owolabi RA. 1997b: Comparative study of metals in fish organs, sediment and water from Nigeria fresh water fish ponds. Pakistan J. Sci. Ind. Res., 40:5-12.

Olowu RA, Ayejuyo OO, Adewuyi GO, Adejoro AI, Denloye AAB, Babatunde AO, Ogundajo AL. 2010. Determination of heavy metals in fish tissues, water and sediment from Epe and Badagry Lagoons, Lagos, Nigeria. E- Journal of Chemistry, 7(1): 215- 221.

Okoye BCO. 1991. Heavy metals and organisms in Lagos Lagoon. International Journal of Environmental Studies, 37: 285-292.

WHO (World Health Organisation). 1993. Guidelines for drinking water quality recommendation $\left(2^{\text {nd }}\right.$ edn). WHO: Paris. 